\title{
Plasma Medicine; How can Nonthermal Atmospheric Plasma be Applied to Medicine?
}

\author{
Sang Rye Park', Jin Woo Hong², Hae June Lee ${ }^{3}$ and Gyoo Cheon Kim ${ }^{1 *}$ \\ ${ }^{1}$ Department of Oral Anatomy, School of Dentistry, Pusan National University, Yangsan 626-870, Korea \\ ${ }^{2}$ Department of Korean Internal Medicine, School of Korean Medicine, Pusan National University, Yangsan 626-870, Korea \\ ${ }^{3}$ Department of Electronics Engineering Pusan National University, Busan 609-735, Korea
}

Received June 5, 2013 /Revised June 20, 2013 /Accepted June 24, 2013

\begin{abstract}
As a forth state of material, plasma is ionized gas, which generates characteristically various reactive species. After late of $20^{\text {th }}$ century, plasma has been widely used in industry. After nonthermal atmospheric plasma was developed, it has been applied to biomedical fields. Nonthermal atmospheric plasma does not give thermal damages to human tissues, and it shows the high efficiency in cancer treatment, sterilization, tooth bleaching, coagulation, and wound healing. Because the application of plasma to biomedicine has been expanded through interdisciplinary studies, its value of high medical technology is increasing now. Since nonthermal atmospheric plasma was first applied to the mammalian cells and microorganisms, many valuable studies has been performed for about last 10 years, so that now the new research area called 'plasma medicine' has been formed. This article introduces the recent data resulted from plasma medicine and helps to understand the plasma medicine.
\end{abstract}

Key words : Nonthermal atmospheric plasma, plasma medicine, reactive species

\section{서 론}

플라즈마(plasma)는 세포에서 세포막을 일컬을 때와 혈액 에서 세포성분을 제외한 나머지 액체성분을 언급할 때 흔히 사용된다. 물리학 또는 전기학에서 일컬어지는 플라즈마는 기 체에 강한 에너지를 공급해서 생겨난 새로운 형태의 물질상태 를 말한다. 지구를 제외한 우주의 대부분이 플라즈마 상태로 되어 있으며, 특히 지구의 에너지원이 되고 있는 태양은 $100 \%$ 플라즈마 상태이다. 이런 플라즈마는 자연에서는 번개나 오로 라로 관찰 되며, 일상에서 흔히 관찰되는 형광등 또한 플라즈 마에 해당된다.

플라즈마라는 용어를 처음 사용한 사람은 1930년경 미국의 'Langmuir'로서, 전기적인 방전으로 인해 생기는 전하를 땐 양이온과 전자들의 집단을 플라즈마라 칭하였다[52]. 플라즈 마는 물질의 상태를 나타내는 것으로 열에너지를 가할 경우 고체, 액체, 기체 상태로 변화하여 제 4 의 상태인 플라즈마가 형성된다[35]. 이때 플라즈마는 초고온에서 음전하를 전자와 양전하를 띤 이온으로 분리된 기체 상태인 '이온화된 기체' 상태이지만 또한 플라즈마가 집단적으로 행동하는 '집단적 행

\section{*Corresponding author}

Tel : +82-51-510-8243, Fax : +82-51-510-8241

E-mail : ki91000m@pusan.ac.kr

This is an Open-Access article distributed under the terms of the Creative Commons Attribution Non-Commercial License (http://creativecommons.org/licenses/by-nc/3.0) which permits unrestricted non-commercial use, distribution, and reproduction in any medium, provided the original work is properly cited. 동(collective behavior)하는 중성입자'와 '전하를 띤 입자들로 서 준중성(quasineutral) 기체' 등으로 표현된다.

20세기 말부터 플라즈마는 산업의 여러 분야에서 응용되어 왔다. 그 예로 네온싸인, 형광등, 자동차 표면처리, 반도체 공 정, PDP TV (plasma display panel) 등으로 많은 분야에서 필수적으로 플라즈마가 이용되고 있다. 플라즈마의 대표적 발 생 방법으로는 상당부분 직류방전을 이용하여 만들어져 있으 며, 직류 방전은 양극과 음극 사이에 전압을 가해주어 방전을 일으켜 플라즈마를 일으키는 방법이다[20]. 이에 따라 플라즈 마는 저온 플라즈마와 고온 플라즈마로 구별할 수 있고, 두개 의 전극 사이에 전압을 걸어주게 되면 전류-전압 관계에 따라 암방전(어두운방전), 글로우 방전(밝은 방전), 아크( $\operatorname{arc}$ ) 방전 으로 나누어 진다. 공업적으로 사용하는 아크 방전은 차단기 및 용사장치에서, 코로나 방전은 전기 집진기 및 탈황, 탈질 등의 환경공학 분야에 적용되며, 저온 글로우 방전 플라즈마 는 반도체 공정에서 주로 표면처리를 위한 증착(plasma enhanced chemical vapor deposition: PECVD), 식각(plasma etch)공정 등이나 금속이나 고분자의 표면처리 등에 이용되고 있다. 이렇듯 다양한 분야에서 응용하여 사용할 수 있는 특성 으로 인해 플라즈마는 차세대 에너지원으로서 현재 주목 받고 있다.

플라즈마에 대한 지속적인 연구를 통하여 소형화 된 저온 상압 플라즈마 장치가 개발되었고, 21세기에 이르러 네덜란 드, 미국, 독일, 영국 등에서 다학제간 공동연구를 통하여 의생 명 분야에 저온 상압 플라즈마가 적용되기 시작했다(Fig. 1). 네덜란드의 Eva Stoffels는 2000년대에 주사기 형태의 플라즈 


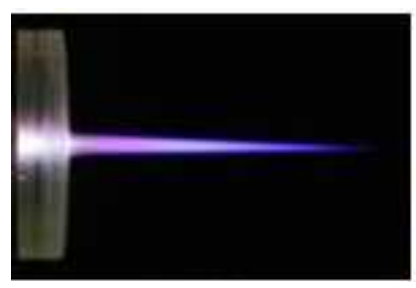

A

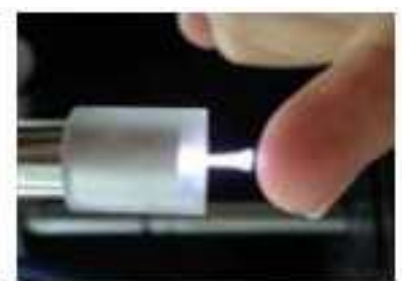

B

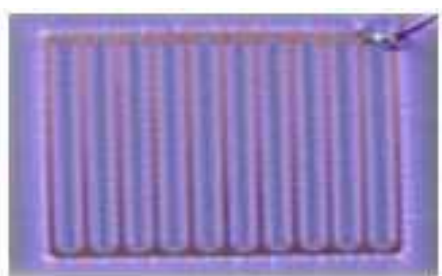

C

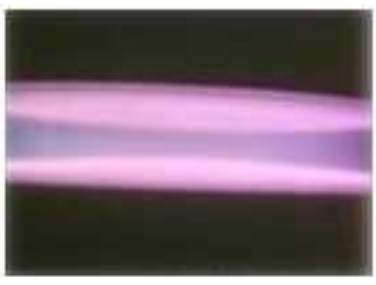

D

Fig. 1. Various types of plasma were shown. Nonthermal atmospheric plasma device has the advantage of being adjustable depending on the use. The pictures show a low frequency plasma (A), microwave plasma (B), air plasma (C), and dielectric barrier discharge plasma (D).

마(needle type plasma)를 이용하여 암세포를 포함한 다양한 포유세포와 미생물에서 플라즈마에 의한 사멸효과를 보고하 였고[47], 이것은 플라즈마 메디신이란 학문영역으로 성장하는 계기가 되었다. 2005년부터 선진국을 주축으로 하여 살균, 암 세포사멸, 지혈, 상처치유에서 매우 주목할 만한 연구결과가 쏟아져 나왔다 $[12,18,36,53]$. 그러나 플라즈마 메디신의 초창 기 연구결과들은 주로 플라즈마 과학자들에 의해 주관이 되어 발표되었기 때문에 그 신뢰성이 다소 떨어졌지만, 최근에는 의생명 과학자들에 의해 주도적으로 이루어진 연구가 보고 되 기 시작해서, 연구결과의 신뢰성과 가치가 한결 높아지고 있 다.

저온 상압 플라즈마는 용어가 제시하는 것처럼 저온을 이용 하기 때문에, 조직에 열적 상해를 주지 않는다. 내시경처럼 사용되는 아르곤 플라즈마는 이미 상용화 되었는데, 이것은 고온에 의존하여 조직을 제거하거나 지혈작용을 하므로 저온 상압 플라즈마의 기전과는 상당히 다르다. 플라즈마의 가장 대표적 특징은 다양하게 발생되는 활성종을 들 수 있을 것이 다. 플라즈마가 직접적으로 세포에 작용하여 효과를 나타내기 도 하나 플라즈마에서 발생하는 활성종의 효과는 암세포 사멸 이나 박테리아 살균에 있어 매우 효과적인 것으로 보고 되고 있다 $[17,59]$. 플라즈마에서 발생되는 다양한 활성종들이 세균 의 세포벽을 파괴시켜 강한 살균효과를 가지며, 흥미롭게도 같은 조건에서 생체조직은 거의 상해를 받지 않는다. 그러므 로, 플라즈마는 세균에 감염된 조직에 매우 뛰어난 효과가 있 으며, 이로 인해 상처치유 과정을 앞당길 수 있다. 플라즈마에 의한 살균 기작은 기존의 항생제가 가지는 내성의 문제점에 대한 좋은 대안이 될 수 있다. 플라즈마에서 발생되는 활성종 은 인체에 무해한 수산화기(hydroxyl radical: $\mathrm{OH} \cdot$ ), ions, electrons, photons, 이온화된 가스와 극소량의 UV 등이 방출 된다. 이 중에서 질소 가스를 이용하여 플라즈마를 발생시 nitric oxide $(\mathrm{NO})$ 가 발생되며, $\mathrm{NO}$ 는 세포의 분화를 촉진시키거 나 상처 치유를 유도하고[26], 동물실험결과 조직의 감염과 급 성 및 만성염증에 있어 효과적인 것으로 나타났다[7, 11, 43]. 그리고 $\mathrm{OH} \cdot$ 은 박테리아 살균에 있어 매우 중요한 역할을 하 는 것으로 알려져 있다[19]. 최근 플라즈마를 이용한 암 치료
연구와 관련하여 많은 논문들이 발표되고 있으며 leukemia cell [50], 흑색종[9]과 같은 암세포 처리에 플라즈마를 조사했 을 때, 암세포의 사멸효과가 높았다. 이러듯 플라즈마는 암세 포 사멸과 박테리아 살균효과에 탁월한 효과를 가지고 있을 뿐만 아니라, 플라즈마에서 발생되는 다양한 radical은 혈액응 고에도 효과가 있는 것으로 나타났다[12]. 저온 플라즈마의 응 용범위는 나날이 넓어지고, 이로 인해 선진국에서는 국가 차 원에서 상당한 연구자금을 연구개발에 투여하고 있다. 한국에 서는 비록 몇몇 연구팀에 의해 괄목할 연구성과를 내고 있지 만 그 규모나 응용범위가 여전히 제한되어 있다. 본 논문은 더 많은 플라즈마 메디신(plasma medicine) 연구팀이 한국에 서 구성될 수 있기를 희망하면서 최근까지 플라즈마 메디신에 대한 연구결과들을 소개하고자 한다.

\section{플라즈마를 이용한 암 치료}

암 치료는 외과적 수술, 방사선 치료, 항암 약물치료 등의 방법으로 치료가 진행 되고 있으나, 현재로서는 수술이 가장 효과적인 치료법으로 받아지고 있다. 그러나 외과적 수술은 정상조직을 포함하여 넓은 부위의 암조직을 절제해야 하며, 방사선 치료의 경우 면역력의 감소로 다른 합병증이 유발될 수 있으며, 항암제 치료의 경우 암세포에 대한 비특이성과 암 세포들의 항암제 내성으로 인해 치료에 있어 한계가 있다. 이 렇듯 암 치료의 부작용을 최소화하기 위한 연구가 현재 활발 히 진행되고 있으며, 최근 나노기술 및 바이오기술, 전기물리 학기술을 응용한 다양한 융합기술들이 대두되고 있다.

그 중에서 최근 플라즈마를 이용한 암세포 제거에 대한 연 구가 시도되고 있다[10, 22, 27, 53, 60]. 저온 상압 플라즈마는 열로서 암세포를 사멸 하는 것이 아니라 플라즈마의 다양한 활성종이 암세포의 괴사(necrosis)나 세포자멸사(apoptosis) 등을 유도하여 세포를 사멸시키게 된다[17, 21, 37, 42]. 플라즈 마에서 발생되는 활성종은 세포의 부착(adhesion)에 중요한 기능을 하는 세포부착 단백질들을 불활성화시켜 세포의 탈착 (detachment)을 유도하여 세포자멸사를 유도한다. 세포의 부 착능력 상실로 인해 나타나는 세포자멸사의 양상(anoikis)은 
암세포 사멸에 아주 중요한 역할을 한다[28]. 다른 사멸 기작으 로서 생쥐 흑색종 세포에 플라즈마를 처리 시, DNA의 손상과 사립체의 기능 장애를 통한 세포자멸사가 보고 되었다[24]. Vandamme 등은 동물모델에서 Glioma cell을 주입한 생쥐에 서 플라즈마를 조사했을 때, 암 조직의 크기가 대조군에 비해 $30 \%$ 의 감소되었음을 보고했다[55].

그러나, 플라즈마 또한 암세포만을 구별해서 사멸시키는 암 특이적 죽음을 유도하진 못한다. 그리하여 선택적 암세포 사 멸을 위해, 암세포에서 특이적으로 과잉 발현되는 단백질을 표적 단백질로 삼아, 이 단백질에 대한 항체를 금 나노입자에 부착을 시켰다. 이 중합체는 암세포만을 특이적으로 부착할 수 있으며, 금 나노입자는 플라즈마의 효과를 증폭시키기 때 문에[51] 정상세포가 영향을 받지 않는 세기의 플라즈마를 조 사하게 되면, 정상세포에는 거의 영향을 미치지 않으면서, 중 합체가 부착된 암세포에 강력한 플라즈마 효과를 집중시켜 암세포 특이적 세포사멸 기술이 소개되었다(Fig. 2). 흑색종 세포인 G361 세포주는 focal adhesion kinase (FAK)를 과잉 발현하고 있어서, FAK에 대한 항체를 금 나노입자에 부착시 켰다. 사용된 플라즈마는 사용전력 $22 \mathrm{khz}$ 의 DBD type의 공 기 플라즈마(air plasma) 형태였다. 흑색종 세포에 금 나노입 자와 FAK를 부착시킨 중합체를 처리한 후 플라즈마를 적용시 킨 결과 대조군들에 비해 중합체와 플라즈마를 처리한 실험군 에서 흑색종 세포의 사멸률은 5 배 이상 높았다[23]. 이러한 결 과는 흑색종 세포 뿐만 아니라 oral squamous cell carcinoma (OSCC)에서도 유사한 결과를 보였다. OSCC에서는 epidermal growth factor receptor (EGFR) 단백질이 과잉 발현되 었으며, EGFR을 표적 단백질로 이용하여 금 나노입자와 플라 즈마를 함께 조사했을 경우, 매우 높은 암 선택적 사멸률을 관찰할 수 있었다[5]. 위의 결과를 바탕으로 저온 상압 플라즈 마를 이용하여 암세포에서 과잉 발현되는 단백질을 표적으로
정상세포와 구별하여 암세포의 전이, 침윤, 증식을 억제 할 수 있을 것이다. 그러나, 비록 플라즈마가 암세포 제거에 높은 선택적 사멸률을 보이지만, 아직 연구의 초기 단계이기 때문 에, 향후 더 많은 연구가 진행될 것으로 기대된다.

\section{치아 미백}

최근 미(美)에 대한 관심이 급격히 증가하는 추세에 따라 심미적 요구가 늘어나면서 더불어 하얀 치아로 만들어 주는 치아미백에 대한 사회적 관심과 욕구가 증대하고 있다. 하얀 치아는 대인관계에서 자신감을 주며 인상을 좌우하는 중요한 요소가 된다[13]. 치아 변색을 일으키는 원인으로는 크게 내인 성과 외인성 요인으로 나뉘어 질 수 있으며, 내인성 변색은 tetracycline 의 복용, 치수충혈, 치수 괴사 등으로 인하여 야기 되며, 외인성 착색으로는 와인, 담배, 커피 등으로 치아의 착색 이 유발되게 된다[56]. 기존 치아미백의 기전은 '산화-환원 반 응'이 주된 기전으로 알려져 있다. 주로 사용하는 미백제는 과산화수소(hydrogen peroxide)이며, 치아미백 과정에서 과 산화수소는 법랑질과 상아질의 유기질 내로 침투하여 작용하 게 되고, 법랑 소주 사이의 축적된 착색물질을 제거하여 미백 효과가 나타나는 것으로 알려져 있다[2]. 치아미백의 대표적인 방법으로는 치과의사의 통제하에 치과 내에서 이루어지는 전 문가 미백과 직접 가정에서 시행하는 자가 미백으로 분류할 수 있다[31]. 전문가 미백은 주로 고농도(30-50\%)의 과산화수 소수와 광원을 이용하여 외부적 착색물을 제거하는 생활치 미백과 충격이나 외상 등으로 치수가 괴사가 일어나 내부적 변색을 제거하는 실활치 미백으로 이루어진다.

본 연구진에서는 고온의 광원이 아닌 저온 상압 플라즈마를 이용하여 치아 미백에 적용한 결과, 생활치 미백 $[29,30]$ 뿐만 아니라 실활치 미백에 있어서도 높은 미백효과를 나타내는

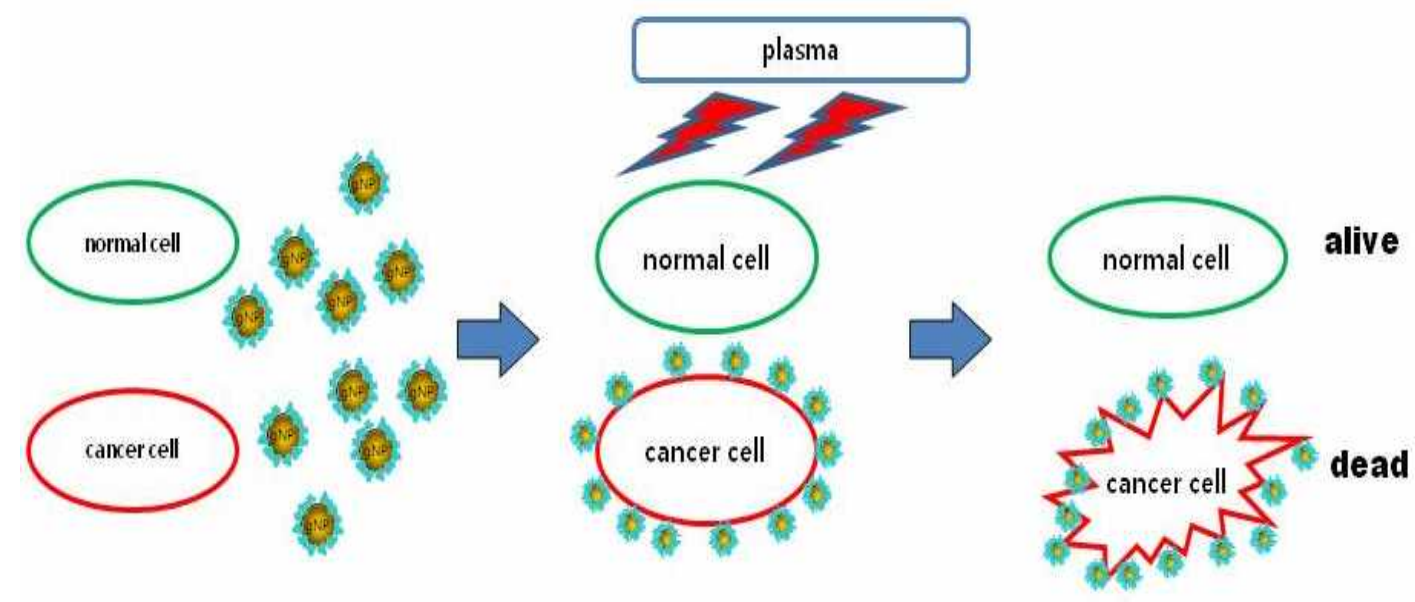

Fig. 2. The schematic picture of selectively killing cancer cells using gold nanoparticle (gNP) and plasma. Cancer cell specific antibodies are conjugated to the gNP that can be stimulated by plasma, thereby the stimulated gNP and plasma kill the cancer cells selectively. 
것을 확인 하였다[39]. $28 \%$ 의 과산화수소와 플라즈마 조사는 과산화수소만 처리한 치아에 비해 약 3 배 높은 미백효과가 있었으며, 이것은 커피나 와인으로 착색시킨 치아에서도 매우 뛰어난 미백효과를 보였다[29]. 실활치 미백은 광원의 특성상 직접 치아에 처리하기가 어려움이 있어 대부분의 경우는 4 주 이상 미백제를 전치부 치아의 lingual cavity에 넣어 둔다. 그 러나, 본 연구진은 헬륨 가스를 이용한 jet type의 저온 상압 플라즈마 장치를 이용하여 혈액으로 변색시킨 치아의 와동에 과산화수소와 함께 30 분 조사한 결과, 미백 효과가 탁월함을 확인 하였다[30]. 헬륨 가스를 이용한 저온 상압 플라즈마를 조사한 과산화수소를 electron spin resonance (ESR) spectrum 측정했을 때, 다량의 - $\mathrm{OH}$ 가 생성됨을 알 수 있었다[31]. • $\mathrm{OH}$ 은 치아 미백에 중요한 역할을 담당하고 있기 때문에, 플라 즈마에 의해 발생한 풍부한 - $\mathrm{OH}$ 로 인하여 치아 표면과 상아 질에 침착된 유기물을 효과적으로 분해하여 치아미백을 이루 는 것으로 알 수 있다. 플라즈마 치아미백의 장점은 발생되는 플라즈마의 온도가 인체와 유사한 $37^{\circ} \mathrm{C}$ 을 유지하기 때문에, 치아에 열손상을 일으키지 않는다[39]. 뿐만 아니라 고농도의 과산화수소는 치주조직과 치수조직의 괴사를 일으킬 수 있으 며, 시술 중 환자에게 심각한 통증을 유발시켜서 사용에 제한 이 있다. 그러나 플라즈마를 이용한 치아미백에서는 $5.4 \%$ 의 과산화수소만으로도 충분한 미백효과를 보이고 있으며, $30 \%$ 과산화수소만 처리한 치아에 비해 약 2 배의 치아미백효과를 보여 준다[38]. 그러므로, 치과 임상 분야에서 저온 플라즈마 장치가 치아미백을 위한 대체 에너지원으로서의 충분한 잠재 력을 보여주고 있다(Fig. 3).

\section{살균작용}

저온 상압 플라즈마의 의생명분야 적용에 있어서, 가장 많 은 성과를 보여준 부분은 미생물 살균이다. 플라즈마는 다양 한 병원균을 살균하는 능력이 발표되면서, 상처 치료기기 또 는 멸균기 등으로 응용되고 있다. 최근 플라즈마를 이용한 구
강 세균 사멸 연구가 최근 활발히 이루어지고 있으며 $[8,36$, 40], 이와 관련된 내용들을 서술하고자 한다.

구강 내 발생하는 대표적 양대 구강질환은 치아우식증 (dental caries)과 치주질환(periodontal disease)이며[3], 이 질 환들은 구강 내 세균이 원인이 되어 발병된다[41]. 치아우식증 의 가장 큰 문제점은 치료가 끝난다 하더라도 재발 위험이 높아 한국인의 대표적 만성 질환으로 대두되고 있다. 치아우 식증 치료 시 치아를 삭제하여 보존치료나 보철치료를 실시하 게 되는데, 이때 흔히 정상 치질까지 침범하여 삭제 되는 문제 점이 있다. 그리고 치근단 부위에 발생되는 질병의 경우 치료 기구의 접근의 어려움으로 인하여 박테리아를 효과적으로 사 멸하기 어렵다. 항생제나 구강 소독액 등이 사용도기도 하나 항생제는 임산부나 전신질환자에 사용하는데 어려움이 있으 며, 구강 소독액을 지나치게 사용할 경우 구강 내 정상 세균총 의 불균형으로 인해 균교대증(superinfection)에 의한 2차적인 감염을 유발 시킬 수 있다. 이에 치아 우식증을 효과적으로 치료하기 위해 예방치료로서 불소도포나 올바른 치솔질 등의 방법이 추천되고 있으나 치아의 깊은 소와나 열구와 같은 해 부학적인 구조 특성상 칫솔모의 접근이 어려워 한계가 있다 [49].

치주 질환은 치은, 치조골, 치주인대 등의 치아 주위조직에 세균으로 인한 염증이 파급되어 치아주위조직이 파괴된다. 치 주세균을 적절하게 억제시키지 않을 경우 치아 주위조직이 치아를 지지하지 못해 발치를 해야 하는 최악의 상황이 초래 하게 된다[54]. 치아우식증이나 치주질환으로 인한 발치 시 치 료비 부담으로 인한 경제적 손실이 크며[3], 이는 결국 가계의 부담을 초래하고, 나아가 국가적 의료비 손실로 이어지게 된 다. 그러므로 치아우식증과 치주질환을 예방하고 치료하기 위 해서는 원인 세균을 적절히 사멸시키는 것이 중요하다.

최근 플라즈마를 이용하여 치아우식증 및 치주질환 원인균 을 효과적으로 사멸시키는 연구가 활발히 진행되고 있다(Fig. 4). 치아우식증에 있어 가장 주된 원인 균인 Streptococcus $m u-$ tans (S. mutans) [34, 44, 46, 58] 균과 치근단에 존재하는

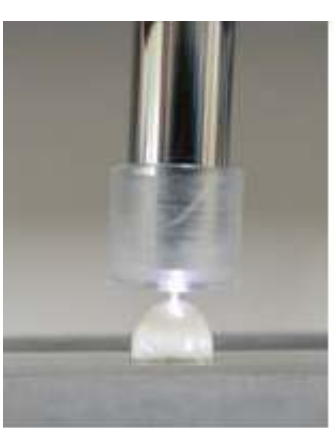

A

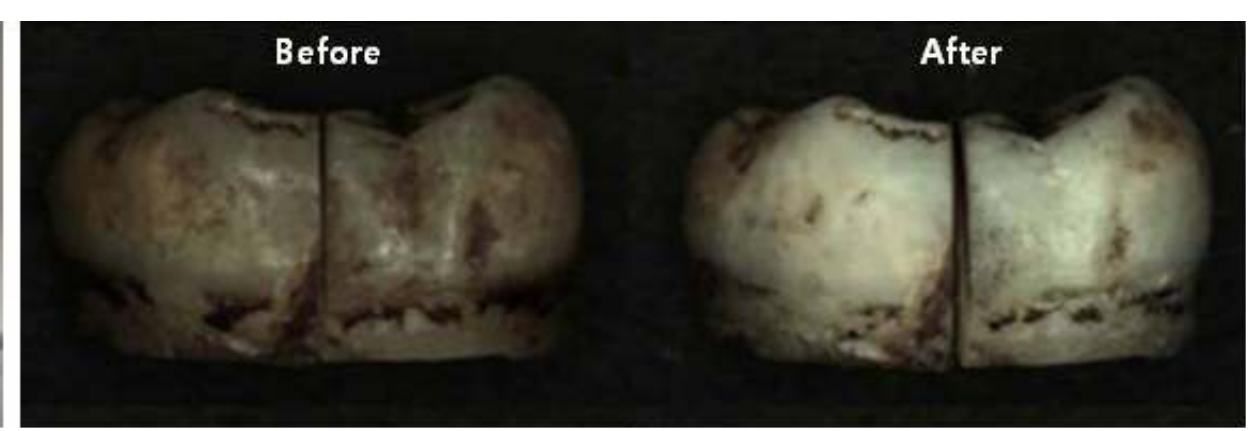

B

Fig. 3. The plasma tooth bleaching. The extracted human tooth was treated with $15 \%$ carbamideperoxide and plasma for 30 min (A). The high bleaching efficiency was observed in the tooth treated with plasma for $30 \mathrm{~min}$ (B). 


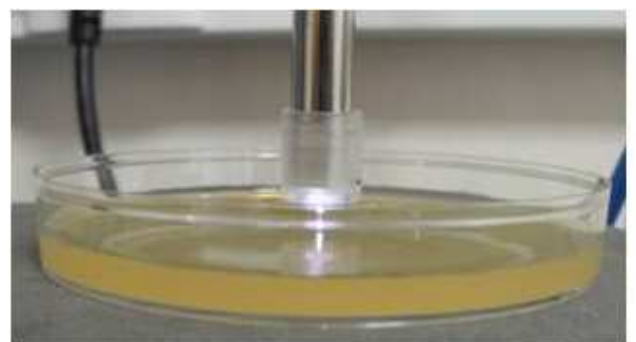

A

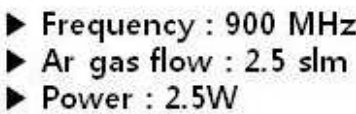

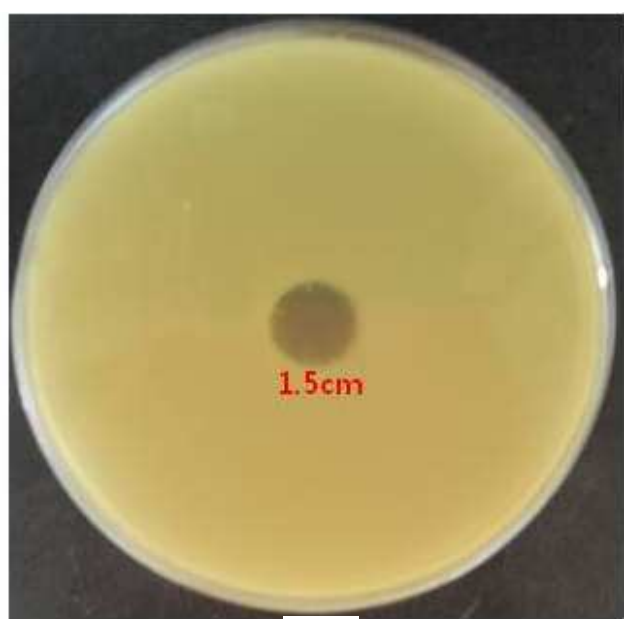

B

Fig. 4. The sterilization of Streptococcus mutans (S. mutans) by plasma. The plasma treatment of the agar plate (A). The microwave plasma showed the sterilizing effect on $S$. mutans from $30 \mathrm{sec}$ and a definite clear zone was formed at $300 \mathrm{sec}$ of plasma treatment (B).

Enterococcus faecalis (E. faecalis) [4, 15], 치주질환 원인균인 Porphyromonas gingivalis (P. gingivalis) [33]의 사멸에 있어서 도 매우 효과적임이 증명되고 있다. S. mutans균은 통성 혐기 성의 그람 양성 균으로 두꺼운 세포벽으로 인해 세포 사멸이 쉽지 않은 특징을 가지고 있다[16]. 치근단 질환의 주요 원인 균인 E. facalisi균은 그람 양성균으로 치아 치근단 부위의 염증 에 관여하며 극한 상황 속에서도 살아 남을 수 있다. E. faecalis 균은 근관 치료시 사용되는 높은 $\mathrm{pH}$ 의 $\mathrm{NaOCl}$, 항생제 및 칼 슘제재와 같은 약품에 저항성이 강하고[32], 근관치료시 효과 적으로 제거되지 않을 경우 근관치료 실패의 가장 큰 원인이 되어 지속적인 감염을 일으키게 된다[57]. 성공적인 치근단 치 료를 위해서는 E. faecalis 균을 효과적으로 제거하는 것이 무엇 보다 중요하다. 최근 보고에 의하면, 저온 상압 플라즈마는 E. faecalis를 효과적으로 사멸시킬 뿐만 아니라, 치아우식증 원인균인 S. mutans 에서도 효과적으로 사멸시키는 것이 보고 되고 있다 $[4,15,34,44,46,58]$. 또한, 사람의 비강과 구강 인후 점막의 상재균으로 화농성 염증을 일으키는 감염증의 주요 원인균인 Staphylococcus aureus (S. aureus) [48]나 구강 내에서 기회감염을 일으켜 구강점막질환을 일으키는 대표적인 진균 인 Candida albicans (C. albicans) 등에서도 매우 효과적인 사멸 효과가 보고되고 있다[25]. 구강 내 질환을 일으키는 세균은 치아우식증이나 치주병 만을 일으키는 것이 아니라 구강점막 질환 및 기타 구강내 염증을 일으키게 된다. 흔히 구강내 염증 이 발생시 구강소독액인 chlorhexidine을 주로 사용하고 있으 나, 발표된 연구에 따르면 플라즈마와 chlorhexidine을 함께 사용할 때 그 효과가 증가 하는 것이 보고 되었는데, 이 결과는 플라즈마를 단독으로 사용하였을 때 구강세균의 사멸률이 뛰 어날 뿐만 아니라 구강 소독약등과 함께 사용하였을 때 시너
지 효과를 기대할 수 있어서, 구강질환 치료에 탁월한 효과를 발휘할 수 있을 것으로 예상된다[25].

물론 열을 가하여 세균을 사멸 시킬 경우 그 효과는 클 수 있으나 조직의 열적 손상을 일으킬 위험이 있다. 그러나 저온 플라즈마 장치는 체온과 유사하게 그 온도를 유지 시킬 수 있어 조직의 손상을 최소로 할 수 있으며, 그와 더불어 안정성 이 뛰어나고, 플라즈마에서 발생되는 활성종으로 인해 직접 플라즈마가 조사되지 않더라도 발생되는 플라즈마 주위영역 까지 세균을 사멸 시킬 수 있다. 이러한 특성을 이용하여 근관 치료 시 플라즈마를 근관에 접근이 용이하게 제작한다면 접근 이 어려운 위치에 있는 세균들을 사멸 및 불활성화 시킬 수 있다. 그러므로 플라즈마 장비를 구강 내 해부학적 구조에 맞게 디자인하여 적용시킨다면 구강 내 질환 치료에 있어 높 은 효과를 기대할 수 있을 것으로 예상 된다.

\section{상처치유}

상처치유과정은 지혈, 염증반응, 조직의 재생, 세포외기질 의 재구성과 같은 일련의 과정을 가진다. 플라즈마에서 발생 되는 다양한 활성종들이 지혈효과나 상처치유 촉진에 영향을 주고 있는 것으로 알려지고 있으며, 이러한 특성을 이용하여 조직 재생 분야에서 플라즈마를 이용한 연구가 활발히 진행 되고 있다. 혈 액에 플라즈마를 처리하였을 경우 20초 이내에 지혈이 되었으며, 항 응고제가 포함된 혈액에서도 뛰어나 지 혈효과가 보고되고 있는데, Kalghatgi 등에 의하면 플라즈마 는 혈액응고에 관여하는 단백질들에 영향을 미쳐 피브린 형성 에 중요한 역할을 하는 것으로 보고되었다[18]. 또한 조직 손상 후 플라즈마 처리 시 살균작용으로 인하여 조직의 2차 감염을 
예방하고 빠른 지혈작용으로 상처치유에 있어서 효과적인 것 으로 나타났다[12]. Heinlin의 보고에 따르면 정맥성 궤양이 발생한 부위에 하루에 2분씩 반복적으로 플라즈마를 처리한 결과 상처치유 효과가 탁월한 것으로 나타났으며, 플라즈마를 반복적으로 11 회 처리 후 상처부위에 세균이 발견되지 않는 것을 확인하였다[14].

Collagen type I은 피부를 포함한 많은 조직의 재생 및 재건 을 위해 매우 중요한 역할을 하고 있다[1]. Fibronectin은 세포 접착, 세포이동, 세포분화조절 등 다양한 생리작용에 관여하 며, 피부의 상처치유나 anti-aging에 있어 중요한 역할을 하고 있다[45]. 피부나 조직 손상 시 vascular endothelial growth factor (VEGF)의 분비는 모세혈관 생성을 증가시켜 손상된 조 직에서 세포성장을 촉진시켜 조직의 강력한 재생효과를 유도 한다. 저온 마이크로 웨이브 플라즈마를 피부세포에 조사했을 때, metallomatrix proteinase (MMP), collagen, fibronectin, VEGF 등의 유전인자의 발현이 증가함을 확인하였다. 이때 플 라즈마로 인한 세포의 열적 손상이나 배지의 $\mathrm{pH}$ 의 변화는 관 찰되지 않았다[6]. 이러한 결과는 상처치유뿐만 아니라 피부미 용 분야에도 중요한 기초 연구결과라 할 수 있다. 즉 피부에 플라즈마의 주기적 처리는 피부세포를 자극시켜 진피층의 콜 라겐을 증가시키고, $\mathrm{VEGF}$ 의 분비 증대로 인해 신생혈관들이 피부세포들의 영양공급을 담당하여 노화 방지 효과를 기대할 수도 있다.

플라즈마에 의한 혈액응고 기전에 대해서는 아직 정확하게 보고된 바는 없으나, 상처 치유와 혈액응고는 밀접한 연관관 계를 가지고 있어, 이와 연관된 지속적인 연구가 이루어진다 면 일반 환자뿐만 아니라 혈액 질환을 가지고 있는 환자의 상처치유에 있어 플라즈마를 아주 유용하게 사용할 수 있을 것이다. 뿐만 아니라, 현재 보고된 내용들을 고려해 볼 때, 플 라즈마는 피부재생이나 피부미용, 화상이나 전신질환으로 인 한 피부조직 손상 시 최소한의 부작용으로 뛰어난 재생효과를 나타낼 수 있을 것으로 기대된다. 향후, 이러한 목적으로 플라 즈마가 임상에 적용되기 위해서는 더 많은 연구가 지속적으로 시행되고, 플라즈마의 안정성 및 사용의 편이성이 더 증명되 어야 할 것이다.

\section{결 론}

오늘날 전 세계적으로 의생명분야 연구에서는 엄청난 노력 이 이루어지고 있으며, 그로 인해 새로운 의료기술이 나날이 개발되고 소개되고 있다. 플라즈마를 이용한 의료기술은 현재 의학적 문제점을 보완하거나 치료기술을 발전시켜, 미래에 많 은 질병들을 치료하고 삶의 질을 향상시킬 수 있는 첨단 의료 기술로서 평가되고 있다. 플라즈마에서 발생되는 활성종들은 살균, 상처치유, 암세포 사멸, 혈액응고와 치아미백 등에서 뛰 어난 효과가 입증되었다. 직진성을 가지는 다른 광원들에 플
라즈마의 회절성, 저온성, 장비 제작의 용이성 등은 세포나 불규칙한 구조의 조직에 손상 없이 적용할 수 있는 큰 장점이 된다. 현재 플라즈마가 갖고 있는 몇몇 단점을 보완하게 된다 면, 임상에서 플라즈마는 차세대 의료기술의 중요한 역할을 할 수 있을 것으로 판단된다.

플라즈마 메디신 연구는 2005년을 전후로 해서 전세계적으 로 급속히 발전했으며, 1 년 6 개월의 주기로 개최되는 "International Conference on Plasma Medicine" 국제학회의 규모도 회를 거듭할수록 성장하고 있다. 본 연구진은 2005년 당시 학술진흥재단의 지원을 받아 “의료용 마이크로 플라즈 마 발생장치 개발 및 세포에 미치는 효과실험"이란 과제를 수행하였는데, 이것이 아마도 국내에서 처음 시도된 플라즈마 메디신 연구였으리라 추정된다. 그 후로도 계속 플라즈마 메 디신 연구를 지금까지 했었기 때문에, 국내·외 플라즈마 메 디신 연구의 발전을 지켜 볼 수 있었다. 비록 국내의 플라즈마 메디신에 관련된 연구집단의 규모는 작기는 하지만, 현재 광 운대, 부산대, 서울대, 아주대, 연세대, 카이스트, 포항공대에 서 꾸준한 연구를 통해 훌륭한 결과들을 소개하고 있다. 본 논문에서 언급한 것 외에, 플라즈마는 줄기세포에 적용되어 줄기세포의 분화 및 세포성장 촉진이 가능하고, 안구에 적용 되어 안 질환에 대한 적용 가능성들이 학회를 통해 알려지고 있다. 플라즈마의 응용범위는 의생명 분야에서 아직도 광장히 많이 남아 있다. 그러므로, 이런 미개척 분야들이 국내 연구자 들의 다양한 융합연구를 통해서 선점되어지기를 희망하고, 그 로 통해 플라즈마 메디신 기술은 한국이 세계적으로 주도하는 나라가 되기를 기대한다.

\section{감사의 글}

이 논문은 부산대학교 자유과제 학술연구비(2년)에 의하여 연구되었음.

\section{References}

1. Badylak, S. F. 2002. The extracellular matrix as a scaffold for tissue reconstruction. Cell Dev Biol 133, 77-83.

2. Berger, S. B., Coelho, A. S., Oliveira, V. A., Cavalli, V. and Giannini, M. 2008. Enamel susceptibility to red wine staining after 35\% hydrogen peroxide bleaching. J Appl Oral Sci 16, 201-204.

3. Chauncey, H. H., Glass, R. L. and Alman, J. E. 1989. Dental caries. Principal cause of tooth extraction in a sample of US male adults. Caries Res 23, 200-205.

4. Chen, W., Huang, J., DU, N., Liu, X. D., LV, G. H., WANG, X. Q., Zhang, G. P., Guo, L. H. and Yang, S. Z. 2012. Deactivation of enterococcus faecalis bacteria by an atmospheric cold plasma brush. Chin Phys Lett 29, 075203.

5. Choi, B. B., Choi, Y. S., Lee, H. J., Lee, J. K., Kim, U. K. and Kim, G. C. 2012. Nonthermal plasma mediated cancer 
cell death: targeted cancer treatment. J Therm Sci Tech-Jpn 7, 399-404.

6. Choi, J. H., Lee, H. W., Lee, J. K., Hong, J. W. and Kim, G. C. 2013. Low-temperature atmospheric plasma increases the expression of anti-aging genes of skin cells without causing cellular damages. Arch Dermatol Res 305, 133-140.

7. Davydov, A. I., Kuchukhid, S. T., Shekhter, A. B., Khanin, A. G., Pekshev, A. V. and Pankratov, V. V. 2004. Clinical evaluation of intraoperative application of air-plasma flow enriched by nitrogen monoxide in operations on the uterus and adnexa. Probl Gynecol Obstet Perinatal 3, 12-17.

8. Ehlbeck, J., Schnabel, U., Polak, M., Winter, J., Woedtke, T., Brandenburg, R., Hagen, T. and Weltmann, K. D. 2011. Low temperature atmospheric pressure plasma sources for microbial decontamination. J Phys D Appl Phys 44, 013002.

9. Fridman, G., Shereshevsky, A., Jost, M. M., Brooks, A. D., Fridman, A., Gutsol, A., Vasilets, V. and Friedman, G. 2007. Floating electrode dielectric barrier discharge plasma in air promoting apoptotic behavior in melanoma skin cancer cell lines. Plasma Chem Plasma Process 27, 163-176.

10. Fridman, G., Friedman, G., Gutsol, A., Shekhter, A. B., Victor, N., Vasilets, V. N. and Fridman, A. 2008. Applied plasma medicine. Review. Plasma Process Polym 5, 503-533.

11. Grigorian, A. S., Grudyanov, A. I., Frolova, O. A., Antipova, Z. P., Yerokhin, A. I., Shekhter, A. B. and Pekshev, A. V. 2001. Application of a new biological factor, exogenous nitric oxide, for the surgical treatment of periodontis. Stomatologiia 80, 80-83.

12. Gregory, F., Marie, P., Manjula, B., Halim, A., Alexander, F., Alexander, G. and Ari, B. 2006. Blood coagulation and living tissue sterilization by floating-electrode dielectric barrier discharge in air. Plasma Chem Plasma Process 26, 425-442.

13. Haywood, V. B. 1999. Current status and recommendations for dentist-prescribed, at-home tooth whitening. Contemp Esthet Restor Pract 3, 2-9.

14. Heinlin, J., Morfill, G., Landthaler, M., Stolz, W., Isbary, G., Zimmermann, J. L., Shimizu, T. and Karrer, S. 2010. Plasma medicine: possible applications in dermatology. J Dtsch Dermatol Ges 8, 968-976.

15. Jablonowski, L., Koban, I., Berg, M. H., Kindel, E., Duske, K., Schröder, K., Weltmann, K. D. and Kocher, T. 2013. Elimination of $E$. Faecalis by a new non-thermal atmospheric pressure plasma handheld device for endodontic treatment. A preliminary investigation. Plasma Process Polym Early View (Online Version of Record published before inclusion in an issue)

16. Jebur, M. S. 2012. Impacts of virulence factors of Streptococcus mutans isolates on the pathogenesis of acute vaginitis. Int J Nurs Midwifery 4, 16-20.

17. Kalghatgi, S., Kelly, C. M., Cerchar, E., Torabi, B., Alekseev, O., Fridman, A., Friedman, G. and Azizkhan-Clifford, J. 2011. Effects of non-thermal plasma on mammalian cells. PLoS One 21, e16270.

18. Kalghatgi, S., Sameer, U., Fridman, G., Cooper, M., Nagaraj, G., Peddinghaus, M., Balasubramanian, M., Vasilets, V. N., Gutsol, A. F., Fridman, A. and Friedman, G. 2007.
Mechanism of blood coagulation by nonthermal atmospheric pressure dielectric barrier discharge plasma. IEEE Trans Plasma Sci 35, 1559-1566.

19. Kang, S. K., Choi, M. Y., Koo, I. G., Kim, P. Y., Kim, Y. S., Kim, G. J., Mohamed, A. A., Collins, G. J. and Lee, J. K. 2011. Reactive hydroxyl radical-driven oral bacterial inactivation by radio frequency atmospheric plasma. Appl Phys Lett 98, 143702.

20. Kim, C. H. New conversing technology; plasma medicine. 2010. Korean J Otorhinolaryngol-Head Neck Surg 53, 593-602.

21. Kim, C. H., Kwon, S., Bahn, J. H., Lee, K., Jun, S.I., Rack, P. D. and Baek, S. J. 2010. Effects of atmospheric nonthermal plasma on invasion of colorectal cancer cells. Appl Phys Lett 96, 243701.

22. Kim, D., Gweon, B., Kim, D. B., Choe, W. and Shin, J. H. 2009. A feasibility study for the cancer therapy using cold plasma. 13th Int Conf Biomed Eng 23, 355-357.

23. Kim, G. C., Kim, G. J., Park, S. R., Jeon, S. M., Seo, H. J., Iza, F. and Lee, J. K. 2009. Air plasma coupled with antibody-conjugated nanoparticles: a new weapon against cancer. J Phys D Appl Phys 42, 032005.

24. Kim, G. J., Kim, W., Kim, K. T. and Lee, J. K. 2010. DNA damage and mitochondria dysfunction in cell apoptosis induced by nonthermal air plasma. Appl Phys Lett 96, 021502.

25. Koban, I., Matthes, R., Hübner, N. O., Welk, A., Meisel, P., Holtfreter, B., Sietmann, R., Kindel, E., Weltmann, K. D., Kramer, A. and Kocher, T. 2010. Treatment of Candida albicans biofilms with low-temperature plasma induced by dielectric barrier discharge and atmospheric pressure plasma jet. New J Phys 12, 073039.

26. Kong, M. G., Keidar, M. and Ostrikov, K. 2011. Plasmas meet nanoparticles-where synergies can advance the frontier of medicine. J Phys D Appl Phys 44, 174014-174018.

27. Laroussi, M. 2009. Low-temperature plasmas for medicine?. IEEE Trans Plasma Sci 37, 714-725.

28. Lee, H. J., Shon, C. H., Kim, Y. S., Kim, S., Kim, G. C. and Kong, M. G. 2009. Degradation of adhesion molecules of G361 melanoma cells by a non-thermal atmospheric pressure microplasma. New J Phys 11, 1-13.

29. Lee, H. W., Kim, G. J., Kim, J. M., Park, J. K., Lee, J. K. and Kim, G. C. 2009. Tooth bleaching with nonthermal atmospheric pressure plasma. J Endod 35, 587-591.

30. Lee, H. W., Nam, S. H., Mohamed, A. A., Kim, G. C. and Lee, J. K. 2010. Atmospheric pressure plasma jet composed of three electrodes: application to tooth bleaching. Plasma Process Polym 7, 274-280.

31. Lim, M. Y., Lum, S. O., Poh, R. S., Lee, G. P. and Lim, K. C. 2004. An in vitro comparison of the bleaching efficacy of $35 \%$ carbamide peroxide with established intracoronal bleaching agents. Int Endod J 37, 483-488.

32. Luddin, N. and Ahmed, H. M. 2013. The antibacterial activity of sodium hypochlorite and chlorhexidine against Enterococcus faecalis: A review on agar diffusion and direct contact methods. J Conserv Dent 16, 9-16.

33. Mahasneh, A., Darby, M., Tolle, S. L., Hynes, W., Laroussi, M. and Karakas, E. 2011. Inactivation of Porphyromonas gin- 
givalis by low-temperature atmospheric pressure plasma. Plasma Med 1, 191-204.

34. Marchal, F., Robert, H., Merbahi, N., Fontagné-Faucher, C., Yousfi, M., Romain, C. E., Eichwald, O., Rondel, C. and Gabriel, B. 2012. Inactivation of Gram-positive biofilms by low-temperature plasma jet at atmospheric pressure. J Phys D Appl Phys 45, 345202.

35. Morfill, G. E., Kong, M. G. and Zimmermann, J. L. 2009. Focus on plasma medicine. New J Phys 11, 115011.

36. Morfill, G. E., Shimizu, T., Steffes, B. and Schmidt, H. U. 2009. Nosocomial infections-a new approach towards preventive medicine using plasmas. New J Phys 11, 115019.

37. Murakami, T., Niemi, K., Gans, T., O'Connell, D. and Graham, W. G. 2013. Chemical kinetics and reactive species in atmospheric pressure helium-oxygen plasmas with humid-air impurities. Plasma Sources Sci Technol 22, 015003.

38. Nam, S. H., Lee, H. W., Cho, S. H., Lee, J. K., Jeon, Y. C. and Kim, G. C. 2013. High-efficiency tooth bleaching using nonthermal atmospheric pressure plasma with low concentration of hydrogen peroxide. J Appl Oral Sci (In press)

39. Park, J. K., Nam, S. H., Kwon, H. C, Mohamed, A. A., Lee, J. K. and Kim, G. C. 2011. Feasibility of nonthermal atmospheric pressure plasma for intracoronal bleaching. Int Endod $J$ 44, 170-175.

40. Park, S. J., Choi, J., Park, G. Y., Lee, S. K., Cho, Y. S., Yun, J. I., Jeon, S. M., Kim, K. T., Lee, J. K. and Sim, J. Y. 2010. Inactivation of $S$. mutans using an atmospheric plasma driven by a palm-size-integrated microwave power module. IEEE Trans Plasma Sci 8, 1956-1962.

41. Petersen, P. E., Bourgeois, D., Ogawa, H., Estupinan-Day. S. and Ndiaye, C. 2005. The global burden of oral diseases and risks to oral health. Bull World Health Organ 83, 661-669.

42. Sensenig, R., Kalghatgi, S., Cerchar, E., Fridman, G., Shereshevsky, A., Torabi, B., Arjunan, K. P., Podolsky, E., Fridman, A., Friedman, G., Azizkhan-Clifford, J. and Brooks, A. D. 2011. Non-thermal plasma induces apoptosis in melanoma cells via production of intracellular reactive oxygen species. Ann Biomed Eng 39, 674-687.

43. Shekhter, A. B., Serezhenkov, V. A., Rudenko, T. G., Pekshev, A. V. and Vanin, A. F. 2005. Beneficial effect of gaseous nitric oxide on the healing of skin wounds. Nitric oxide 12, 210-219.

44. Sladek, R. E., Filoche, S. K., Sissons, C. H. and Stoffels, E. 2007. Treatment of Streptococcus mutans biofilms with a nonthermal atmospheric plasma. Lett Appl Microbiol 45, 318-323.

45. Sottile, J., Hocking, D. C. and Langenbach, K. J. 2000. Fibronectin polymerization stimulates cell growth by RGD-dependent and -independent mechanisms. J Cell Sci 113, 4287-4299.

46. Stefan, R., Lehmann, A., Hannig, M., Barbara, S. F., Schubert, A., Feldmann, U. and Schindler, A. 2010. Killing of adherent oral microbes by a non-thermal atmospheric plasma jet. $J$ Med Microbiol 59, 206-212.

47. Stoffels, E., Kieft I. E., Sladek, R. E. J., van den Bedem, L.
J. M., van der Laan, E. P. and teinbuch, M. 2006. Plasma needle for in vivo medical treatment: recent developments and perspectives. Plasma Sources Sci Technol 15, S169-S180

48. Sureshkumar, A., Sankar, R., Mandal, M. and Neogi, S. 2010. Effective bacterial inactivation using low temperature radio frequency plasma. Int $J$ Pharm 396, 17-22.

49. Tenuta, L. M., Zamataro, C. B., Del Bel Cury, A. A., Tabchoury, C. P. and Cury, J. A. 2009. Mechanism of fluoride dentifrice effect on enamel demineralization. Caries Res 43, 278-285.

50. Thiyagarajan, M., Gonzales, X. F. and Anderson, H. 2013. Regulated cellular exposure to non-thermal plasma allows preferentially directed apoptosis in acute monocytic leukemia cells. Stud Health Technol Inform 184, 436-442.

51. Tiwari P. K., Kang, S. K., Kim G. J., Choi, J., Mohamed A. A. and Lee, J. K. 2009. Modeling of nanoparticle-mediated electric field enhancement inside biological cells exposed to AC electric fields. Jpn J Appl Phys 48, 087001.

52. Langmuir, I. 1928. Oscillations in ionized gases. Proc NatI Acad Sci USA 14, 627-637.

53. Tuhvatulin, A. I., Sysolyatina, E. V., Scheblyakov, D.V., Logunov, D.Y., Vasiliev, M. M., Yurova, M. A., Danilova, M. M., Petrov, O. F., Naroditsky, B. S., Morfill, G. E., Grigoriev, A.I., Fortov, V. E., Gintsburg, A. L. and Ermolaeva, S. A. 2012. Non-thermal plasma causes p53-dependent apoptosis in human colon carcinoma cells. Acta Naturae 4, 82-87.

54. Upadhyaya, C. and Humagain, M. 2009. The pattern of tooth loss due to dental caries and periodontal disease among patients attending dental department (OPD), Dhulikhel Hospital, Kathmandu University Teaching Hospital (KUTH), Nepal. Kathmandu Univ Med J 7, 59-62.

55. Vandamme, M., Robert, E., Pesnel, S., Barbosa, E., Dozias, S., Sobilo, J., Lerondel, S., Pape, A. L. and Pouvesle, J. M. 2010. Antitumor effect of plasma treatment on U87 Glioma Xenografts: Preliminary results. Plasma Process Polym 7, 264-273.

56. Watts, A. and Addy, M. 2001. Tooth discolouration and staining: a review of the literature. Britdent J 190, 309-316.

57. Williams, J. M., Trope, M., Caplan, D. J. and Shugars, D. C. 2006. Detection and quantitation of E. faecalis by Real-time PCR (qPCR), reverse transcription-PCR (RT-PCR), and cultivation during endodontic treatment. J Endod 32, 715-721.

58. Yang, B., Chen, J., Yu, Q., Li, H., Lin, M., Mustapha, A., Hong, L. and Wang, Y. 2011. Oral bacterial deactivation using a low-temperature atmospheric argon plasma brush. $J$ Dent 39, 48-56.

59. Yusupov, M., Neyts, E. C., Khalilov, U., Snoeckx, R., van Duin, A. C. T. and Bogaerts, A. 2012. Atomic-scale simulations of reactive oxygen plasma species interacting with bacterial cell walls. New J Phys 14, 093043.

60. Zhang, X., Li, M., Zhou, R., Feng, K. and Yang, S. 2008. Ablation of liver cancer cells in vitro by a plasma needle. Appl Phys Lett 93, 021502. 
초록 : 플라즈마 메디신; 저온 상압 플라즈마는 어떻게 의학분야에 적용될 수 있는가?

\section{박상례 ${ }^{1} \cdot$ 홍진우 $^{2} \cdot$ 이해준 ${ }^{3} \cdot$ 김규천 $^{1}{ }^{*}$}

(부산대학교 치의학 전문대학원 구강해부학 교실, ${ }^{2}$ 부산대학교 한의학 전문대학원, ${ }^{3}$ 부산대학교 전자전기공학부)

플라즈마는 물질의 제 4 의 상태로서 이온화된 가스로 불리며 다양한 활성종 및 수산화기, 하전입자, 이온, 자유 전자, 산소등을 발생시키는 특징을 가지고 있다. 20세기 후반에 플라즈마는 산업현장에서 활발히 사용되고 있으 며, 최근 저온 상압 플라즈마 장치가 개발되면서 의생명 분야에 적용되기 시작했다. 저온 상압 플라즈마는 인체조 직에 열 손상을 입히지 않을 뿐만 아니라, 암 치료, 살균, 치아미백, 지혈, 상처치유 등에서 높은 효율성을 보이고 있다. 이때 발생되는 활성종은 포유세포나 병원균에 영향을 미치는 것으로 알려져 있다. 또한, 다학제간의 연구를 통해 저온 상압 플라즈마의 활용범 위는 다양한 영역으로 넓어지고 있으며, 새로운 첨단 의료기술로서의 가치가 높아지고 있다. 저온 상압 플라즈마가 포유세포와 미생물에 적용된 이후, 지난 10 여 년간 급속한 발전을 통해 최근 플라즈마 메디신이란 학문영역으로 성장했다. 본 논문은 저온 플라즈마가 적용되고 있는 분야에 대해 소개 하고, 플라즈마 메디신에 대한 이해를 돕고자 한다. 